\title{
Casein kinase II inhibits the DNA-binding activity of Max homodimers but not Myc/Max heterodimers
}

\author{
Steven J. Berberich and Michael D. Cole \\ Department of Molecular Biology, Lewis Thomas Laboratory, Princeton University, Princeton, New Jersey 08544-1014
}

\begin{abstract}
Max is a heterodimeric partner of the Myc oncoprotein with sequence-specific DNA-binding activity. We found that the DNA-binding activity of bacterially expressed Max homodimers was inhibited in an ATP-dependent reaction by phosphorylation in vitro with purified bovine casein kinase II (CKII). In contrast, phosphorylation of Max and/or Myc by CKII had no inhibitory or stimulatory effect on the DNA-binding activity of $\mathrm{Myc} / \mathrm{Max}$ heterodimers. By deletion analysis and site-directed mutagenesis, the inhibitory domain was localized to a CKII phosphorylation site in the amino terminus of Max. Finally, extracts prepared from NIH-3T3 cell lines that overexpress Max contained a phosphorylated Max protein which, following phosphatase treatment or heterodimerization with Myc, was capable of sequence-specific DNA-binding activity. Immunoprecipitation experiments confirmed that Max was also phosphorylated in NIH-3T3 cells, demonstrating that Max phosphorylation may have an important physiological function.
\end{abstract}

[Key Words: Casein kinase II; Max homodimers; Myc/Max heterodimers; DNA-binding activity]

Received September 19, 1991; revised version accepted December 12, 1991

The c-myc oncogene is frequently activated by different mechanisms in diverse types of cancers, including lymphomas, neuroblastomas, and small cell lung carcinomas (for review, see Cole 1986; Lüscher and Eisenman 1990). Transfection of activated c-myc genes demonstrates that c-Myc protein promotes tumor formation and controls cellular proliferation and differentiation. The c-Myc protein has recently been shown to function as a sequence-specific DNA-binding protein that requires dimerization with a second, related protein called Max (Blackwood and Eisenman 1991; Prendergast et al. 1991). Max, like c-Myc, contains adjacent basic (b)/helix-loop-helix (HLH)/leucine repeat (LR) structures (Landschulz et al. 1988; Murre et al. 1989) that are also present in transcription factors such as TFE3 (Beckmann et al. 1990), AP-4 (Hu et al. 1990), and upstream stimulating factor (USF) (Gregor et al. 1990). Presumably, the Myc/Max heterodimer binds to and trans-activates a set of cellular target genes that participate in the different biological processes.

Myc and Max share significant homology within the DNA-binding and protein dimerization domains. An optimized binding site for Myc has been determined (GACCACGTGGTC), but this site also binds well to USF/ major late transcription factor (MLTF) (Halazonetis and Kandil 1991). Furthermore, the Max protein itself can homodimerize and bind with high affinity to the same sequence (Berberich et al. 1992). Thus, the recognition of specific cellular promoters by the Myc/Max heterodimer could potentially be competed by USF, TFE3, or Max homodimers. It is therefore important to understand the precise promoter recognition requirements and the relative stoichiometry of each complex, as well as any potential regulation of DNA-binding activity/specificity.

In contrast to the $\mathrm{b} / \mathrm{HLH} / \mathrm{LR}$ domains, the remaining regions of Myc and Max show no homology, and the proteins are quite different in size and regulation. Max is a relatively small protein (160 amino acids) that has an extremely long half-life (S. Berberich, unpubl.), in contrast to Myc, which is larger (439 amino acids) and has a very short half-life (20 min) (Hann et al. 1984). The amino-terminal half of the Myc protein can trans-activate transcription when fused to the GAL4 DNA-binding domain (Kato et al. 1990), but no data are available for Max, which has only a small carboxy-terminal domain besides that implicated in DNA binding. Also, unlike Myc, Max can homodimerize efficiently and bind to the same DNA sequence as the Myc/Max heterodimer (Berberich et al. 1992). Thus, in quiescent cells where Max is expressed in the absence of Myc, the question arises as to potential independent functions for Max homodimers versus Myc/Max heterodimers. We have begun to study the relative contribution of the two proteins to target gene activation, as well as the stoichiometry of the two proteins in normal and myc-transformed cells.

To develop a substrate for assays of the different domains of the Max and Myc proteins, we initally focused on determining the optimal binding site of the Myc/Max 
heterodimer and Max homodimer. Although we were able to demonstrate specific DNA binding with bacterially expressed proteins, we were unable to detect DNA binding with in vitro-translated Max protein (S. Berberich, unpubl.), consistent with one recent report (Blackwood and Eisenman 1991). Another study demonstrated only very limited DNA-binding activity of Max (Prendergast et al. 1991). The disparity between bacterially expressed and in vitro-translated protein suggested that a modification of Max could eliminate the DNA-binding activity of Max homodimers. Given several recent studies in which phosphorylation of transcription factors plays a direct role in their DNA-binding capabilities (Sorger and Pelham 1988; Yamamoto et al. 1988; Lüscher et al. 1990; Manak et al. 1990; Boyle et al. 1991; Kapiloff et al. 1991) and the probability that Max, like c-Myc, was a phosphoprotein, we explored the role of phosphorylation on Max and Myc/Max DNA-binding activity. Here, we report that the DNA-binding capability of Max homodimers is reduced sharply by casein kinase II (CKII) phosphorylation, but Myc/Max heterodimer binding is unaffected. Moreover, we have identified phosphorylated Max proteins in NIH-3T3 cell lines that demonstrate DNA-binding activity only after phosphatase treatment or by protein dimerization with Myc. These results suggest that phosphorylation of Max has an important physiological role in modulating or eliminating any potential competition for Myc/Max target genes by Max homodimers.

\section{Results \\ DNA-binding activity of bacterially expressed Max and Myc proteins}

To study the DNA-binding activity of both homo- and heterodimers of murine Myc and Max proteins, we have employed an oligo-histidine vector system (Abate et al. 1990 ) to express different forms of each protein in large amounts. We produced both full-length Max and the amino-terminal 110 amino acids [Max(n110)], as well as soluble truncated forms of murine c-Myc as either the carboxy-terminal 249 [Myc(c249)]- or 118 [Myc/c118)]amino-acid proteins (Fig. 1A). Electrophoretic mobilityshift assays (EMSAs), using these bacterially expressed proteins with a previously determined high-affinity DNA-binding site (MMC) (Berberich et al. 1992), demonstrated that Max can both heterodimerize with Myc (Fig. 1B, lanes 5,6) and also homodimerize (Fig. 1B, lanes 1-3). The exchange between Myc and Max, or between different forms of Max, was dependent on a preincubation for $10 \mathrm{~min}$ at $30-37^{\circ} \mathrm{C}$ or on corenaturation (S. Berberich, unpubl.). In contrast to the results obtained with bacterial Max, we were unable to demonstrate DNAbinding activity with Max protein synthesized by in vitro translation in reticulocyte lysate ( $R L)$, consistent with results from other laboratories. We were interested in determining the cause of this dramatic difference in the activity of proteins produced by the different techniques.

A

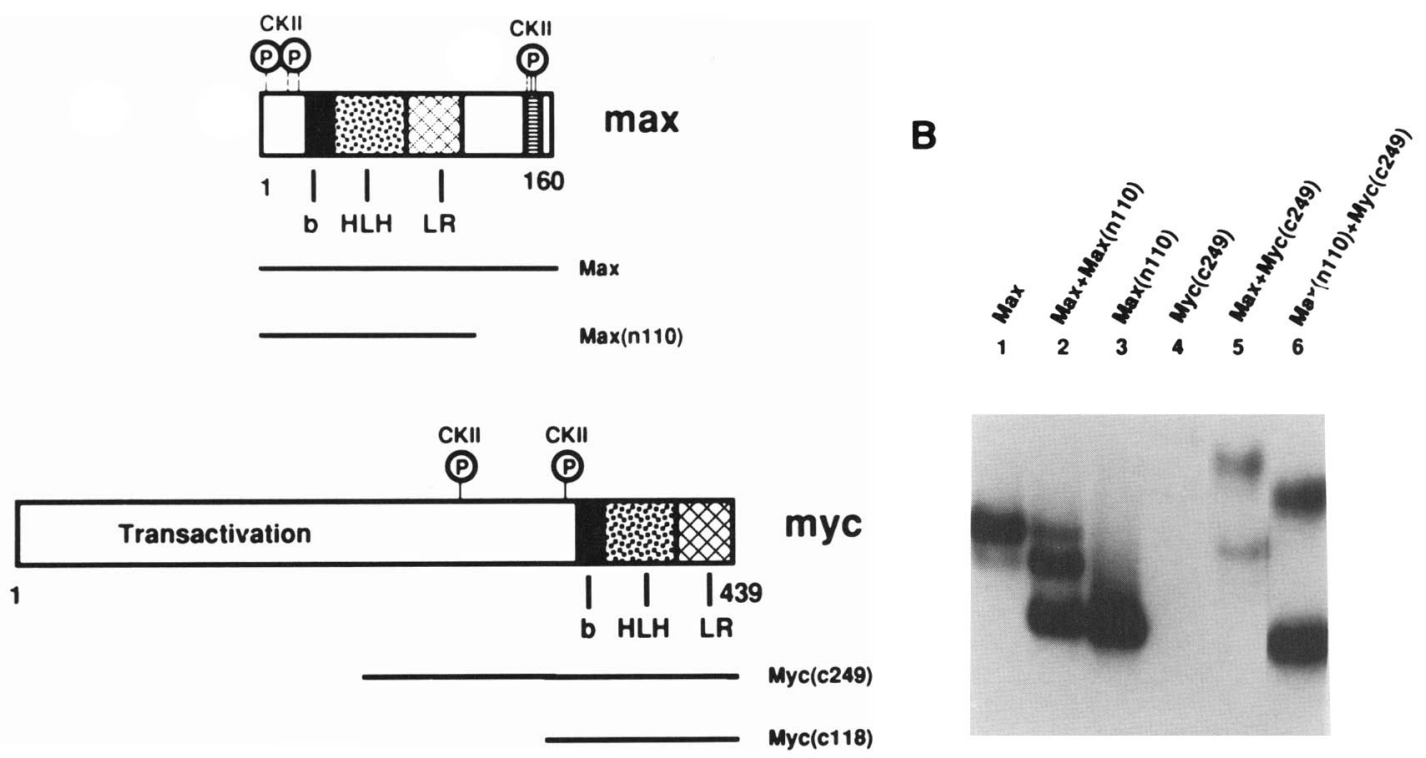

Figure 1. Diagram and specific DNA-binding activity of Max and c-Myc proteins. (A) A diagram of Max (top) and Myc (bottom) proteins, showing the positions of the b/HLH/LR motifs. (b) Basic amino acid region, solid box; (HLH), helix-loop-helix region, stippled box; (LR) leucine repeat region, crosshatched box. CKII phosphorylation sites are indicated [CKII(P)]; an acidic domain in Max is shown as a lined box. The proteins produced in bacteria for the experiments in this study are shown by solid lines as Max/160 amino acids, $21 \mathrm{kD}$ ), Max(n110) (110 amino acids, $18 \mathrm{kD}$ ), Myc/c249) (249 amino acids, $29 \mathrm{kD}$ ), and Myc(c118) (118 amino acids, $18 \mathrm{kD})$. All proteins produced in vitro contain an amino-terminal histidine fusion. $(B)$ EMSAs were performed using the high-affinity binding site for Myc/Max and Max dimers (MMC, GACCACGTGGTC) with the following bacterially expressed proteins: (Lane 1) $100 \mathrm{ng}$ of Max; (lane 2) $100 \mathrm{ng}$ of $\mathrm{Max}+50 \mathrm{ng}$ of Max(nl10); (lane 3) $50 \mathrm{ng}$ of Max(nl10); (lane 4) $400 \mathrm{ng}$ of Myc(c249); (lane 5) $100 \mathrm{ng}$ of Max +400 $\mathrm{ng}$ of Myc(c249); (lane 6) $50 \mathrm{ng}$ of $\mathrm{Max}(\mathrm{n} 110)+400 \mathrm{ng}$ of Myc(c249). Conditions for protein exchange and band shift are described in Materials and methods. 
We initially tested whether RL contained an activity that was inhibitory to DNA binding by incubating bacterial Max and/or Myc proteins in RL and assaying for binding to a high-affinity probe by EMSA. The DNAbinding activity of Max was completely eliminated after 10 min incubation in RL, whereas the DNA-binding activity of $\mathrm{Myc} / \mathrm{Max}$ heterodimers was resistant to this inhibitory activity (data not shown). Thus, we began to explore the role of phosphorylation on Myc and Max DNA binding. On the basis of previous reports that (1) CKII phosphorylation could enhance (Manak et al. 1990) or inhibit (Lüscher et al. 1990) the DNA-binding activity of DNA-binding proteins, (2) potential CKII sites are present in both Myc and Max (Fig. 1A; Lüscher et al. 19891, and (3) endogenous CKII activity exists within rabbit reticulocyte lysates (Hathaway and Traugh 1979), we reasoned that CKII activity might be modulating the binding activity of Max.

\section{CKII inhibits Max DNA-binding activity}

First, we tested whether the bacterially expressed Max and Myc proteins could be phosphorylated in vitro with bovine CKII la gift of D. Marshak, Cold Spring Harbor Laboratory, Cold Spring Harbor, NY). The proteins were incubated with CKII and $\left[\gamma^{32} \mathrm{P} \mid \mathrm{ATP}\right.$ and then analyzed on an SDS-polyacrylamide gel (Fig. 2). CKII was able to phosphorylate each of the proteins, consistent with the presence of consensus recognition sites for the enzyme. On the basis of Western blot experiments with myc antisera (data not shown), the lower bands in Myc(c249) represent truncated forms of $\mathrm{Myc}$ protein devoid of DNA-binding activity (Fig. 1B, lanes 4-6).

The effects of CKII phosphorylation on the DNA-binding activity of Max and Myc/Max proteins were analyzed by EMSA. Max, Max(n1 10), and Myc(c249) proteins were incubated individually with bovine CKII enzyme in the presence of $100 \mathrm{~mm} \mathrm{ATP}(+\mathrm{P})$ or AMP-PNP for $30 \mathrm{~min}$ at $30^{\circ} \mathrm{C}$ and then used in EMSA reactions (Fig. 3). As was the case in reticulocyte lysates, phosphorylated Max dimers were unable to bind to the high-affinity Max DNA-binding site (cf. lanes 1 and 2). The inhibition of DNA-binding activity was reversible by phosphatase treatment (not shown). It was also possible to assay the DNA-binding activity of homodimers in which only one-half of the dimer was phosphorylated. Incubation of full-length and truncated forms of Max allows the resolution of two different homodimeric complexes as well as an intermediate mobility complex with subunits of different sizes. The full-length Max protein was phosphorylated and then allowed to exchange with unphosphorylated $\operatorname{Max}(\mathrm{n} 110)$ (which lacks the carboxy-terminal 50 amino acids and one set of CKII sites; Fig. 1A). As before, no DNA binding was observed for full-length Max homodimers, but the unphosphorylated truncated $\operatorname{Max}(\mathrm{n} 110)$ bound DNA well (cf. lanes 3,4). Furthermore, there was a 20 -fold reduction in DNA-binding activity in Max homodimers where only one of the two proteins are phosphorylated (intermediate complex in lanes 3 and 4). Thus, phosphorylation of only one of the two Max sub-

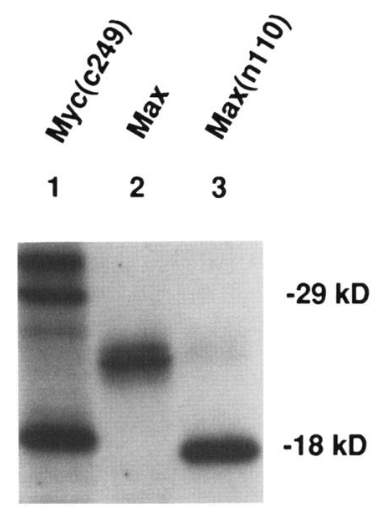

Figure 2. Purified CKII can phosphorylate bacterially expressed Max and Myc proteins in vitro. One to two picomoles of bacterially expressed Myc(c249) (lane 1), Max (lane 2), or $\operatorname{Max}(\mathrm{n} 110)$ (lane 3) was incubated in a $30-\mu$ l reaction $(50 \mathrm{~mm}$ Tris-Cl at pH $8.5,100 \mathrm{mM} \mathrm{NaCl}, 10 \mathrm{~mm} \mathrm{MgCl}$ ) with $15 \mu \mathrm{Ci}$ of $\left[\gamma^{-32} \mathrm{P}\right] \mathrm{ATP}$ and $100 \mathrm{~mm}$ ATP for $30 \mathrm{~min}$ at $30^{\circ} \mathrm{C}$. The reactions were terminated by adding SDS-sample buffer. Phosphorylated proteins were resolved on a $12.5 \%$ SDS-polyacrylamide gel and autoradiographed. Lower bands in Myc(c249) represent carboxyterminal truncated forms of Myc protein devoid of DNA-binding activity that arise in our bacterial expression system with this particular construct. Because the protein is isolated by means of an amino-terminal 6xHis, the amino terminus should be intact in all of the proteins. These truncated proteins would not be expected to bind DNA or dimerize with Max, because mutagenesis has shown that disruption of the Myc leucine zipper inactivates the protein (Stone et al. 1987) and this domain would be lost in the carboxy-terminal truncations.

units was sufficient to inhibit DNA-binding activity of the homodimer. Inhibition of Max homodimer-binding activity was reversible by phosphatase treatment (data not shown).

Very different results were obtained when phosphorylated Max protein was dimerized with Myc/c249). Myc protein itself has little DNA-binding activity (Fig. 3, lanes 13,14$)$ but binds efficiently when dimerized with Max (lane 6). The DNA-binding activity of the heterodimer was equivalent when complexes were formed with either unphosphorylated (lane 6) or phosphorylated (lane 5) Max protein. We note that the migration of the heterodimer is altered by Max phosphorylation, with the modified complex migrating reproducibly faster. The quantitative shift in this migration rate is consistent with complete modification of the Max protein. Thus, even though phosphorylation of only one-half of a Max homodimer eliminates most DNA-binding activity (lane 3 ), the same modified protein binds DNA well when dimerized with Myc.

To begin a preliminary localization of the phosphorylation sites responsible for the inhibition of Max DNAbinding activity, the activity of phosphorylated $\operatorname{Max}(\mathrm{n} 110)$ was monitored (lanes 7-12). As noted above, $\operatorname{Max}(\mathrm{n} 110)$ lacks a cluster of CKII sites near the carboxyl terminus of Max protein (Blackwood and Eisenman 1991). As with full-length Max, the truncated Max(n110) was devoid of DNA-binding activity when phosphory- 

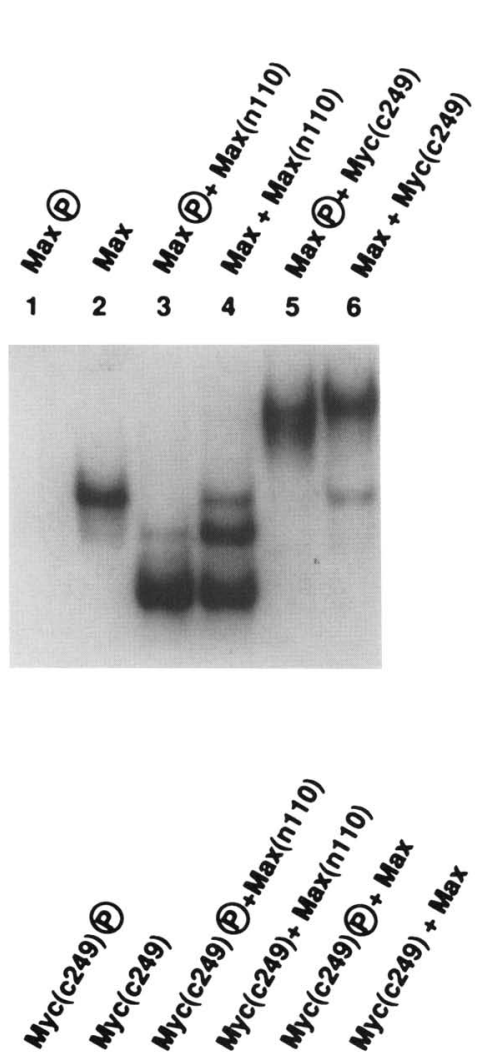

$\begin{array}{llllll}13 & 14 & 15 & 16 & 17 & 18\end{array}$
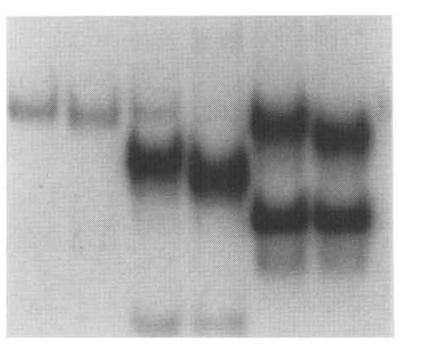
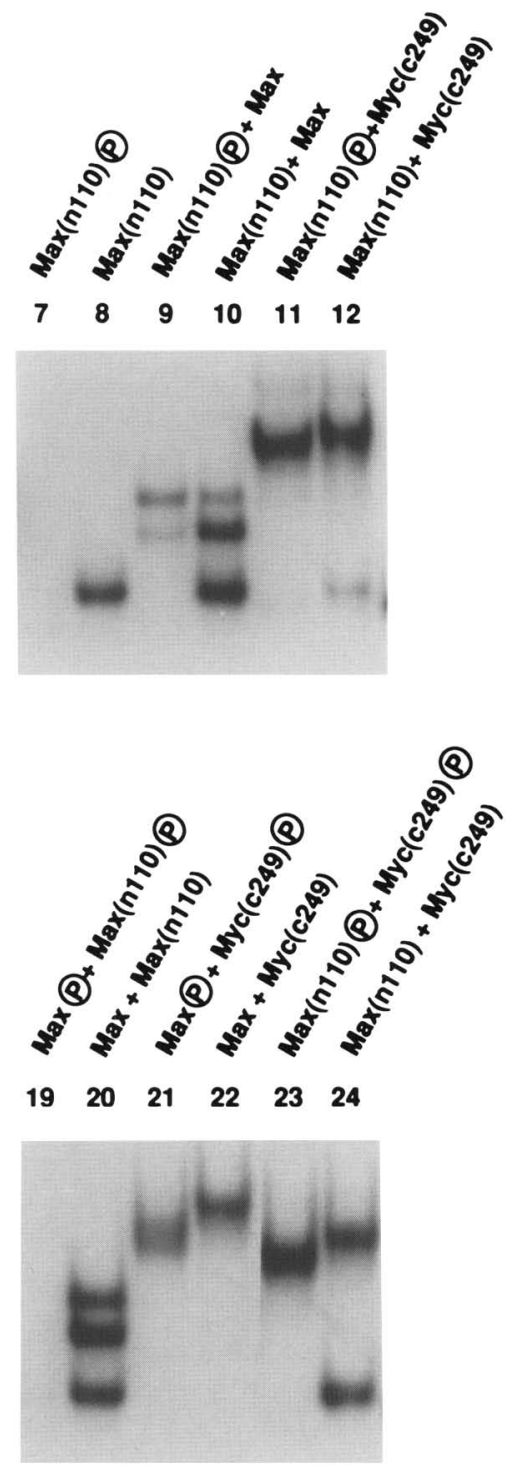

Figure 3. CKII phosphorylation of Max protein inhibits DNA binding of Max homodimers but not c-Myc-containing dimers. EMSAs were performed using bacterially expressed proteins that were incubated with bovine CKII in the presence of ATP or AMP-PNP (Materials and methods). The proteins were combined in band-shift assays that contained 5 mM AMP-PNP and the MMC probe. (Top) The DNA-binding activities of in vitro CKII-phosphorylated Max (left) or Max(n110) (right) were compared with those of unphosphorylated forms. (Bottom left) DNA-binding activity of phosphorylated $\mathrm{Myc} / \mathrm{c} 249)$ was compared with unphosphorylated Myc(c249). (Bottom right) The DNA-binding activity of fully phosphorylated Max and Myc/Max heterodimers was compared with unphosphorylated forms. Experiments with Max protein employed 50-100 ng/lane, and $\mathrm{Myc}$ protein was added in fourfold molar excess. In lanes 17,18 , and 20, approximately twofold more Max protein was included. lated by CKII (cf. lanes 7 and 8). When mixed with unphosphorylated Max, the pattern obtained was consistent with dramatically reduced DNA-binding activity for any Max/Max complex that contained a single phosphorylated protein (cf. lanes 9 and 10). These results imply that the phosphorylation of one or a combination of the remaining three CKII phosphorylation sites amino-terminal to the basic region functions to inhibit Max DNAbinding activity in vitro (see Fig. 8A, below). Finally, as with full-length Max, Max $(\mathrm{n} 110)$ is capable of binding DNA as a Myc/Max heterodimer, irrespective of its phosphorylation state (lanes 11,12). The Myc protein also contains CKII sites adjacent to the basic region that are known to be phosphorylated in vivo and can be phosphorylated in vitro by purified enzyme (Lüscher et al. 1989). In contrast to Max, phosphorylation of Myc(c249) to completion did not effect the DNA-binding activity of Myc/Max heterodimers (Fig. 3, lanes 15-18) or the weak binding activity of Myc homodimers (lanes 13,14). We believe that CKII phosphorylation was complete from the migration rate of phosphorylated Myc/Max heterodimers. This complex migrated slightly slower in reactions containing phosphorylated Myc protein (lanes $15,17)$ compared with complexes formed with unphosphorylated Myc (lanes 16,18), suggesting that the population of Myc proteins was completely phosphorylated in these reactions. A similar shift was evident in the weak binding activity of Myc homodimers (lanes 13,14).

In the final EMSA panel, dimers were completely phosphorylated (lanes 19,21,23) or unphosphorylated (lanes 20,22,24) and then allowed to exchange before the DNA-binding activity was analyzed. Again, Max dimers lacked discernible DNA-binding activity, whereas Myc/ Max heterodimers showed no loss of DNA-binding activity. Therefore, phosphorylation of a single Max subunit is sufficient to inhibit the DNA-binding capacity of the Max homodimer, but fully phosphorylated Myc/Max heterodimers retained complete DNA-binding activity. 
A potential explanation for the loss of DNA-binding activity with Max homodimers is that phosphorylation inhibited dimer formation. To test that hypothesis, phosphorylated and unphosphorylated Max proteins were subjected to glutaraldehyde protein cross-linking to determine the amount of Max homodimers (Fig. 4). Max protein (phosphorylated or unphosphorylated) was incubated with increasing concentrations of glutaraldehyde and analyzed by SDS-PAGE. Equivalent amounts of cross-linked homodimer (Fig. 4, complex $>43 \mathrm{kD}$ ) were formed with phosphorylated and unphosphorylated Max. Therefore, we conclude that phosphorylation of Max does not inhibit homodimer formation but, instead, affects DNA binding alone.

In an attempt to determine the CKII phosphorylation site that inhibited Max homodimer DNA-binding activity, we used site-directed mutagenesis to convert the serine at amino acid 11 to an alanine (see Fig. 8A, below). We reasoned that this site was most likely involved in the inhibitory effect, because it was the optimal CKII site of the three potential CKII sites present amino-terminal to the basic domain (D. Marshak, pers. comm.). Max, Max(A11), and Myc(c249) were phosphorylated individually, as described above, and analyzed by EMSA for DNA-binding ability using the MMC probe. As shown in Figure 5, phosphorylated Max homodimers are incapable of binding to the high-affinity DNA-binding site, whereas phosphorylated Myc(c249)/Max heterodimers bind as avidly as unphosphorylated heterodimers do (Fig. 5, cf. lanes 1 and 2 with 5 and 6). In striking contrast, phosphorylated Max(A 11$)$ bound to the MMC probe with

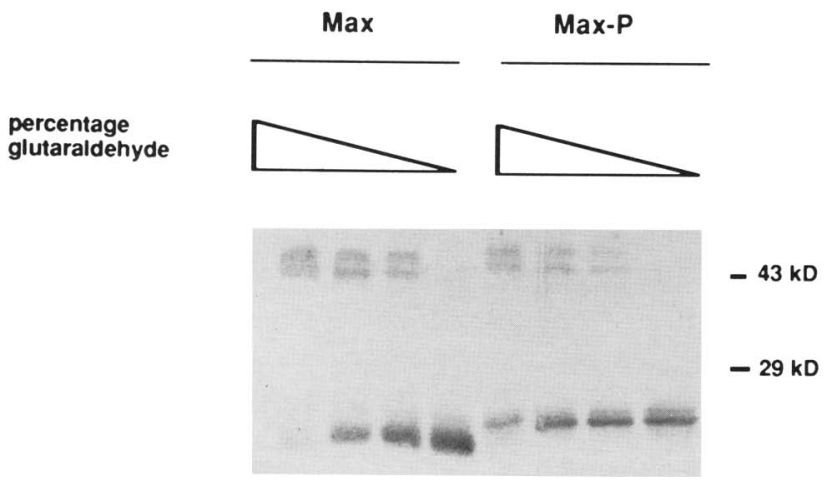

Figure 4. Glutaraldehyde cross-linking of Max homodimers. Glutaraldehyde cross-linking of Max homodimers was performed as described in Materials and methods. Briefly, $200 \mathrm{ng}$ of Max protein, treated previously with CKII + ATP (phosphorylated) or CKII + AMP-PNP (unphosphorylated), was incubated with $0 \%, 0.001 \%, 0.005 \%$, or $0.025 \%$ glutaraldehyde for $30 \mathrm{~min}$ at $30^{\circ} \mathrm{C}$. Cross-linking reactions were inactivated with SDSsample buffer. Proteins were analyzed on a $12.5 \%$ SDS-polyacrylamide, transferred to nitrocellulose, and probed with the Max polyclonal antisera. The amount of cross-linked Max homodimers $(>43 \mathrm{kD})$ appears to increase at an equivalent rate with Max (lanes 1-4) and phosphorylated Max (lanes 5-8, MaxP) as the percentage of glutaraldehyde was increased. Uncrosslinked Max protein runs below the $29-\mathrm{kD}$ marker.

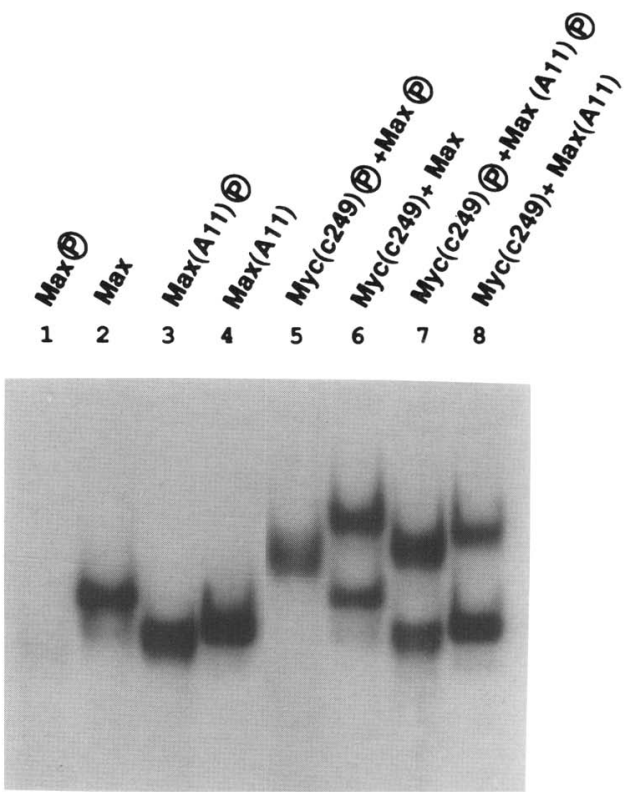

Figure 5. Site-directed mutagenesis of serine 11 reverses inhibition of DNA binding of phosphorylated Max homodimers. EMSAs were performed as described in Fig. 3. Proteins were allowed to dimerize for $10 \mathrm{~min}$ at $37^{\circ} \mathrm{C}$ before the addition of the MMC probe. The shift in migration of the phosphorylated Max(A11) homodimer and Myc/Max heterodimer complexes relative to unphosphorylated complexes is consistent with complete phosphorylation of the bacterially expressed proteins.

an affinity equivalent to that of the unphosphorylated form (lanes 3,4). Furthermore, mutation of S1l had no effect on Myc/c249)/Max DNA binding, and the activity of the residual Max(A11) homodimers was retained in the reactions (lanes 7,8 ). Therefore, we conclude that the conversion of serine 11 to an alanine identifies one of the sites of CKII phosphorylation through which Max homodimer DNA-binding activity was inhibited.

\section{Max is phosphorylated in NIH-3T3 cell lines}

To determine whether the modulation of Max DNAbinding activity by phosphorylation was important within the cell, we initally analyzed two NIH-3T3 cell lines that overexpress Max protein. The two cell lines (MaxD, MMB) were derived from NIH-3T3 cell lines that were stably transfected with cytomegalovirus (CMV)max, and CMV-max and CMV-myc expression vectors, respectively. Both MaxD and MMB cells overexpress Max protein $\sim 5$ - to 10 -fold over NIH-3T3 cells, on the basis of both Northern and immunoprecipitation analysis (data not shown).

When nuclear extracts were prepared from these cell lines and tested by EMSA with the high-affinity binding site for Max and Myc/Max dimers, no unique DNAprotein complex was detected that contained either Max or Myc/Max proteins (Fig. 6, lanes 2,8; Fig. 7A, lane 1). The shifted complexes that are observed (labeled a) are probably the result of endogenous USF/MLTF protein. In 
light of the results on Max phosphorylation, we decided to assay the DNA-binding activity after phosphatase treatment. In both cell lines, a fast-migrating DNA-protein complex (b) appears in phosphatase-treated extracts (Fig. 6, lanes 1,9|, and this complex is disrupted with Max polyclonal antibodies (lanes 5,13) but not with preimmune sera (lanes 3,11) or Myc polyclonal antibodies (lanes 7,15). The heterogeneity of the DNA-protein complex in MaxD extracts when compared with MMB extracts is the result of incomplete dephosphorylation of MaxD reactions. Because the migration of complex $b$ is comparable to that of Max homodimers formed in vitro, we assume that the complex detected in the nuclear extracts is also a homodimer. Thus, Max protein exists in a non-DNA-binding form in nuclear extracts, but DNA binding can be activated by phosphatase. We presume that the protein exists as an inactive homodimer in untreated extracts, but this remains unclear without direct analysis of dimerization.

We note that no Myc/Max heterodimeric complex can be resolved in normal or phosphatase-treated extracts, which would be evident as a complex disrupted by both Myc and Max antiserum (Fig. 6). The myc polyclonal antisera are capable of disrupting bacterially expressed Myc proteins in Myc/Max heterodimers (S. Berberich, unpubl.), suggesting that it is possible to identify Myc DNA-binding complexes within these extracts. On the basis of the phosphorylation results discussed above, such a complex should be active in DNA binding even in the absence of phosphatase. We are uncertain as to why such a complex is not visible; this could be the result of poor solubilization from nuclei, masking by other complexes, or instability of the heterodimer.

We then wished to determine whether the DNA-binding activity of the Max protein in nuclear extracts could be unmasked by forming heterodimers using bacterially expressed Myc protein in the absence of phosphatase treatment, as demonstrated in vitro. Myc/c249) was added to the extracts, which were then incubated at $37^{\circ} \mathrm{C}$ to promote dimer exchange and analyzed by EMSA (Fig. 7A). The apparent Max homodimer complex in potato acid phosphatase (PAP)-treated extracts (complex d) was quantitatively converted to a more slowly migrating form (complex b), consistent with the migration of Myc(c249)/Max dimers identified in vitro (Fig. 3). More importantly, a novel complex (c) was observed in extracts incubated with $\mathrm{Myc}(\mathrm{c} 249)$ alone; this complex is not observed with Myc(c249) protein itself (Fig. 3, lane 14). The formation of this complex is consistent with it being a heterodimer between the endogenous, phosphorylated Max protein and the added Myc(c249), which was confirmed by immunoprecipitation (data not shown). The migration of complex $c$ is significantly faster than that of the heterodimer in phosphatase-treated extracts (complex b). This difference is probably the result of the multiple phosphorlyation sites on Max protein modified within the cell, which is consistent with the faster migration of complexes formed with phosphorylated Max protein in vitro (Fig. 3). Thus, as demonstrated in vitro, the DNA-binding activity of phosphorylated Max protein produced within cells is unmasked by dimerization with Myc.

Finally, we wished to address the phosphorylation state of Max in normal NIH-3T3 cells. Using unfractionated nuclear extracts, it was necessary to employ the overexpressing cell lines because the level of endogenous Max protein was extremely low. To circumvent this problem, Max protein was isolated from NIH-3T3 cells by a low-stringency immunoprecipitation with Max polyclonal antiserum and analyzed by EMSA (Fig. 7B). No Max DNA-binding complex was detected when the renatured immunoprecipitated protein was assayed for DNA-binding activity with the MMC probe (Fig. 7B, lane 1). However, when $\alpha \mathrm{Max}$ immunoprecipitates were allowed to dimerize with either Myc(c249) (lane 2) or Myc(c118) (lane 3), heterodimer complexes were evident that were not present in reactions containing only the bacterially expressed Myc proteins (lanes 5,6). These re-
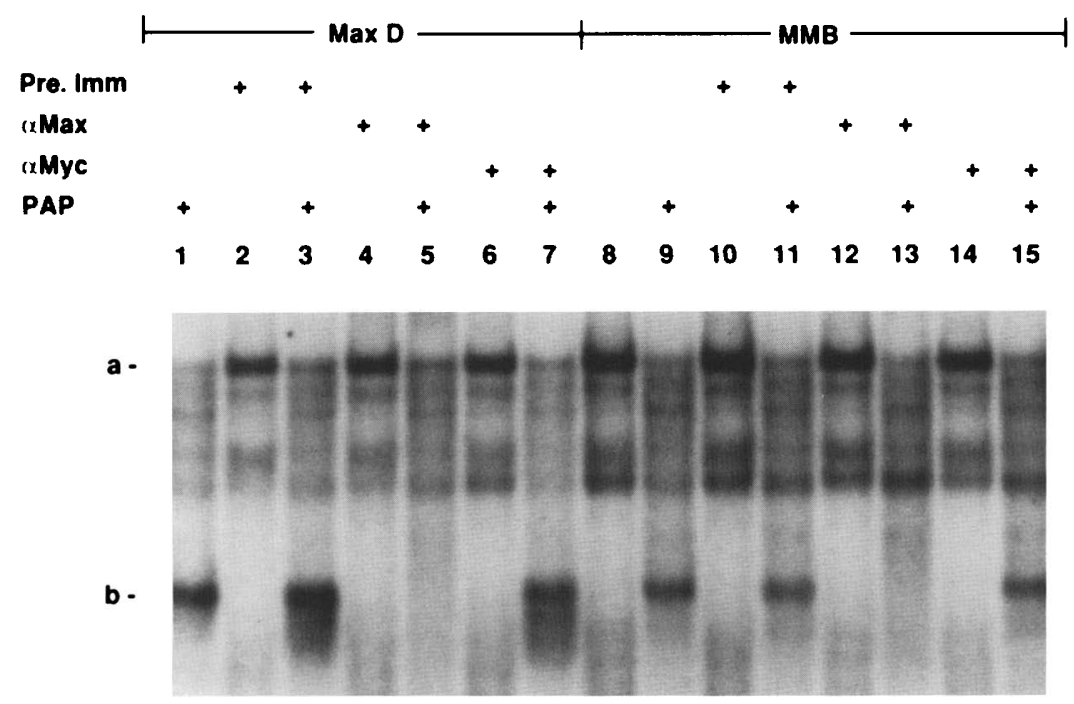

Figure 6. Max protein overexpressed in NIH3T3 cell lines is phosphorylated and devoid of DNA-binding activity. Nuclear extracts from either MaxD (left) or MMB (right) cell lines were incubated in gel-binding buffer $\pm 1.5 \mu \mathrm{g}$ of potato acid phosphatase (PAP) for $15 \mathrm{~min}$ at $37^{\circ} \mathrm{C}$. Bandshift reactions were performed as described in Materials and methods. Antisera against Max ( $\alpha$ Max, rabbit polyclonal senum), Myc ( $\alpha$ Myc, rabbit polyclonal serum), or preimmune serum (Pre. Imm, rabbit preimmune serum) were added to the reactions as indicated. $(a)$ The position of endogenous USF/MLTF; $(b)$ the Max-related band. 
Figure 7. Myc(c249) can heterodimerize with in vivo-phosphorylated Max protein. $|A|$ EMSAs were performed using MaxD nuclear extracts preincubated for $10 \mathrm{~min}$ at $37^{\circ} \mathrm{C}$ either alone (lane 1) or with $1.5 \mu \mathrm{g}$ of PAP (lane 2), 600 ng of Myc(c249) (lane 3), and $1.5 \mu \mathrm{g}$ PAP +600 ng of Myc(c249) (lane 4), followed by the addition of $10^{5} \mathrm{cpm}$ of the MMC probe. The migration of different complexes is indicated: $(a)$ DNA-binding activity of Myc/c249) homodimers; (b) DNA-binding activity of Myc(c249) + unphosphorylated Max protein; (c) DNA-binding activity of Myc(c249) + phosphorylated Max protein; (d) DNA-binding activity of unphosphorylated Max protein. $(B)$ EMSAs were performed using immunoprecipitated Max protein from NIH-3T3 cells (Materials and methods/ preincubated for $10 \mathrm{~min}$ at $37^{\circ} \mathrm{C}$ alone (lane 1), with $600 \mathrm{ng}$ of $\mathrm{Myc}(\mathrm{c} 249$ ) (lane 2), or $100 \mathrm{ng}$ of $\mathrm{Myc}(\mathrm{cll18}$ ) (lane 3), followed by the addition of $10^{5} \mathrm{cpm}$ of MMC probe. The arrows indicate the positions of Myc/Max heterodimers. Lanes 5 and 6 contain $\mathrm{Myc}(\mathrm{c} 249)$ and $\mathrm{Myc}(\mathrm{cl} 18)$ in the absence of immunoprecipitated Max protein. The slow-moving band in lanes 2 and 5 is excess $\mathrm{Myc}(\mathrm{c} 249)$ homodimer.

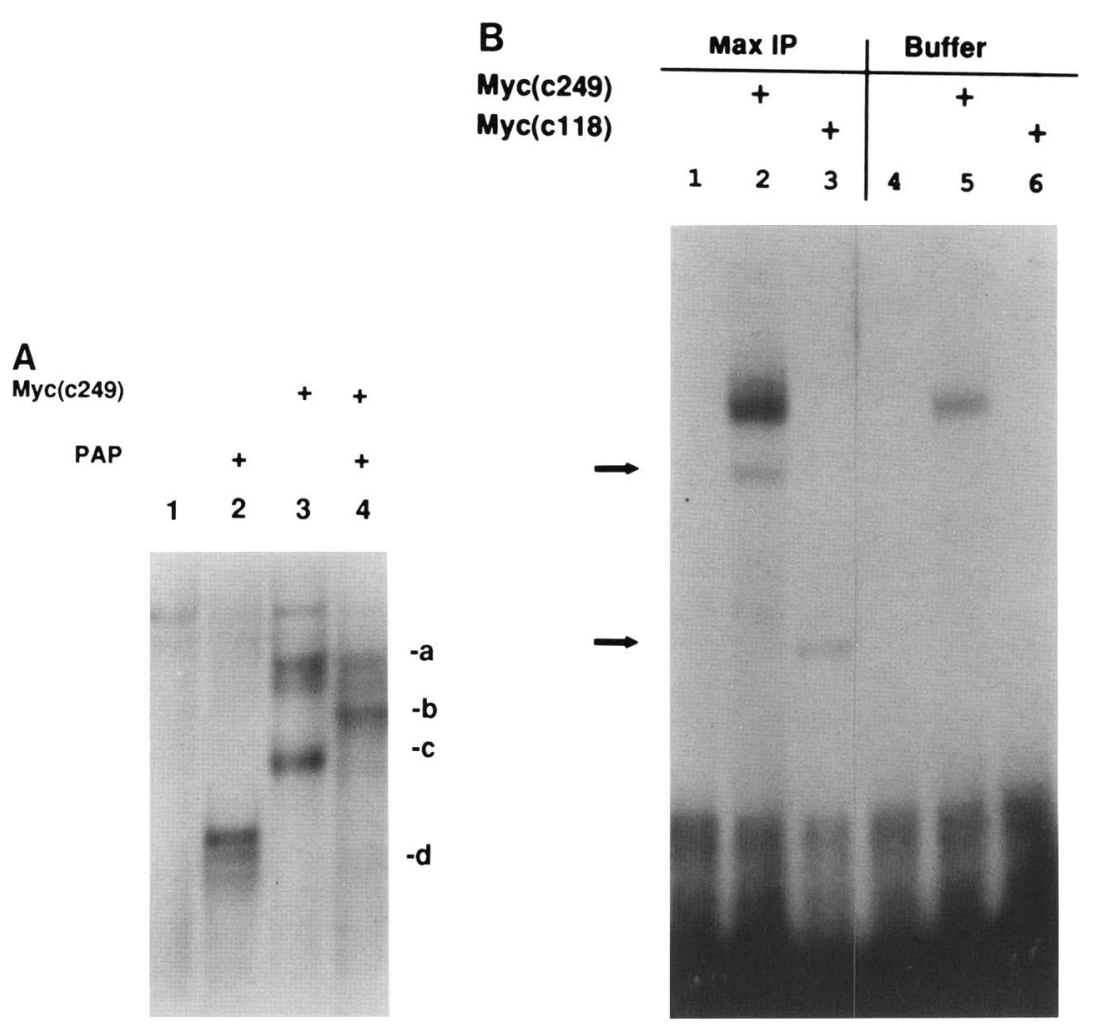

sults suggest that the Max protein in dividing NIH-3T3 cells is similar to that in the overexpressing cell lines and lacks DNA-binding activity except when heterodimerized with Myc.

\section{Discussion}

Considerable evidence suggests that protein phosphorylation/dephosphorylation has a key regulatory role in the cell cycle, transcription, and signal transduction (Yamamoto et al. 1988; Boulton et al. 1991; Boyle et al. 1991). For transcription factors, phosphorylation has been shown to modulate either the trans-activating ability or DNA-binding activity of proteins that participate in a number of regulatory pathways. We show here that the Myc and Max proteins are also subject to phosphorylation that has a major effect on their DNA-binding activities. The exact function of CKII phosphorylation of these factors requires further mutational analysis, but two basic models for the role of Max modification can be envisioned. In the simplest case, the phosphorylation of Max may serve as a constant dampening mechanism to reduce or eliminate the DNA-binding activity of Max homodimers within the cell. The need for this may arise from the nature of the Myc protein itself, which has minimal dimerizing and DNA-binding activity in the absence of a heterodimeric partner. Because Myc is induced by growth factors and required for progression though the cell cycle, a Myc partner must be available at these times for function. Myc dimerization with Max or some similar partner is almost certainly required because mu- tations that disrupt the Myc HLH or LR are inactive in all assays of function to date (Stone et al. 1987; Freytag et al. 1990; Smith et al. 1990). A partner must either be coregulated with Myc or expressed constitutively, and the latter appears to be the case for Max because it is not regulated by serum growth factors or elevated in mycinduced tumors (Berberich et al. 1992). The consequence of this requirement for a partner is that if Max can dimerize and bind DNA itself, it may potentially compete with the Myc/Max heterodimer in target gene recognition. The suppression of Max DNA-binding activity by phosphorylation eliminates this complication, allowing a pool of Max protein to exist in the cell in a comparatively benign form, yet remain available for complex formation with Myc. One question that is critical in understanding the relative contributions of different dimeric forms is the relative stoichiometry of Myc and Max proteins, which is presently under investigation.

To demonstrate that the phosphorylation of Max was physiologically important, it was necessary to use extracts prepared from cell lines that overexpress Max to monitor binding. It could be argued that the inactivation of Max in these lines was an altered phosphorylation pattern specific to these lines that enabled them to compensate for the abnormally high level of Max protein present. The Max immunoprecipitation results with NIH-3T3 cells suggest that this is not the case and that Max is also phosphorylated in normal cells. It is important to point out that none of the data in this study address the question of which phosphorylation sites within native Max protein are responsible for the inhi- 
bition of DNA binding, nor have we shown that CKII phosphorylates serine 11 in vitro. We are currently mapping the sites of phosphorylation for Max protein and analyzing the activity of mutant proteins.

Interestingly, many features of the Myc/Max paradigm parallel the more thoroughly studied transcription factors Fos/Jun. For example, only one partner is induced and cannot homodimerize (fos, $m y c)$, whereas the other partner is relatively constitutive and can homodimerize (jun, $\max$ ). In addition, the DNA-binding activity of Jun can also be down-regulated by phosphorylation, and the modification site is remarkably similar in its location adjacent to the basic region as the CKII sites in Max, although a GSK-3-related enzyme may be responsible for Jun phosphorylation (Boyle et al. 1991). This similarity suggests an alternate model to that discussed above in which the phosphorylation of Max and, hence, DNAbinding activity, is regulated at specific stages of the cell cycle. In its unphosphorylated state, Max dimers could bind to the same promoters that are regulated by $\mathrm{Myc} /$ Max heterodimers and induce some different response such as repression (Fig. 8). Preliminary CAT assay results using a concatamerized high-affinity DNA-binding site suggest that Max may exist transiently in an unphosphorylated homodimer capable of binding to and repressing Myc/Max target genes (S. Berberich, unpubl.).

On the basis of the in vitro phosphorylation data and the presence of consensus sites, we presume that the enzyme responsible for Max protein phosphorylation in vivo is CKII. CKII is a ubiquitous kinase that has been shown to be localized to both the nucleus and cytoplasm
(Hathaway and Traugh 1979) and to phosphorylate serine and threonine residues positioned within clusters of acidic residues (Edelman et al. 1987). Potential in vivo CKII sites have also been identified in Myc and Myb oncoproteins and the E7 viral protein (Firzlaff et al. 1989; Lüscher et al, 1989, 1990). CKII activity has been reported to be induced by mitogenic stimulation in several systems (Sommercorn et al. 1987; Karlund and Czech 1988; Ackerman and Osheroff 1989; Carroll and Marshak 1989), but this stimulation is relatively small (1.5to 6-fold) and no concordant enhancement in the phosphorylation of a cellular substrate has been reported. On the other hand, the subcellular localization of CKII has recently been shown to differ though the cell cycle; in particular, the enzyme migrates out of the nucleus in $S$ phase (Gauthier-Rouviere et al. 1991; Yu et al. 1991). This might suggest a model whereby Max DNA-binding activity that is present in quiescent cells is diminished following mitogenic stimulation by both CKII phosphorylation of Max and induction of Myc protein, and/or elevated in S phase when CKII activity in the nucleus is reduced and phosphatase PP2A activity rises (Fig. 8B; Cohen 1988). We are presently exploring the potential regulation of Max phosphorylation in vivo.

The structural basis for the inhibition of DNA-binding activity by phosphorylation is intriguing. Although Max is a relatively small protein, three potential CKII sites exist amino-terminal to the basic region and a cluster (five) of sites exist within an acidic domain carboxy-terminal to the LR (Fig. 1A). Because the carboxy-terminal deletion $\operatorname{Max}(\mathrm{n} 110)$ is still inhibited by phosphorylation,

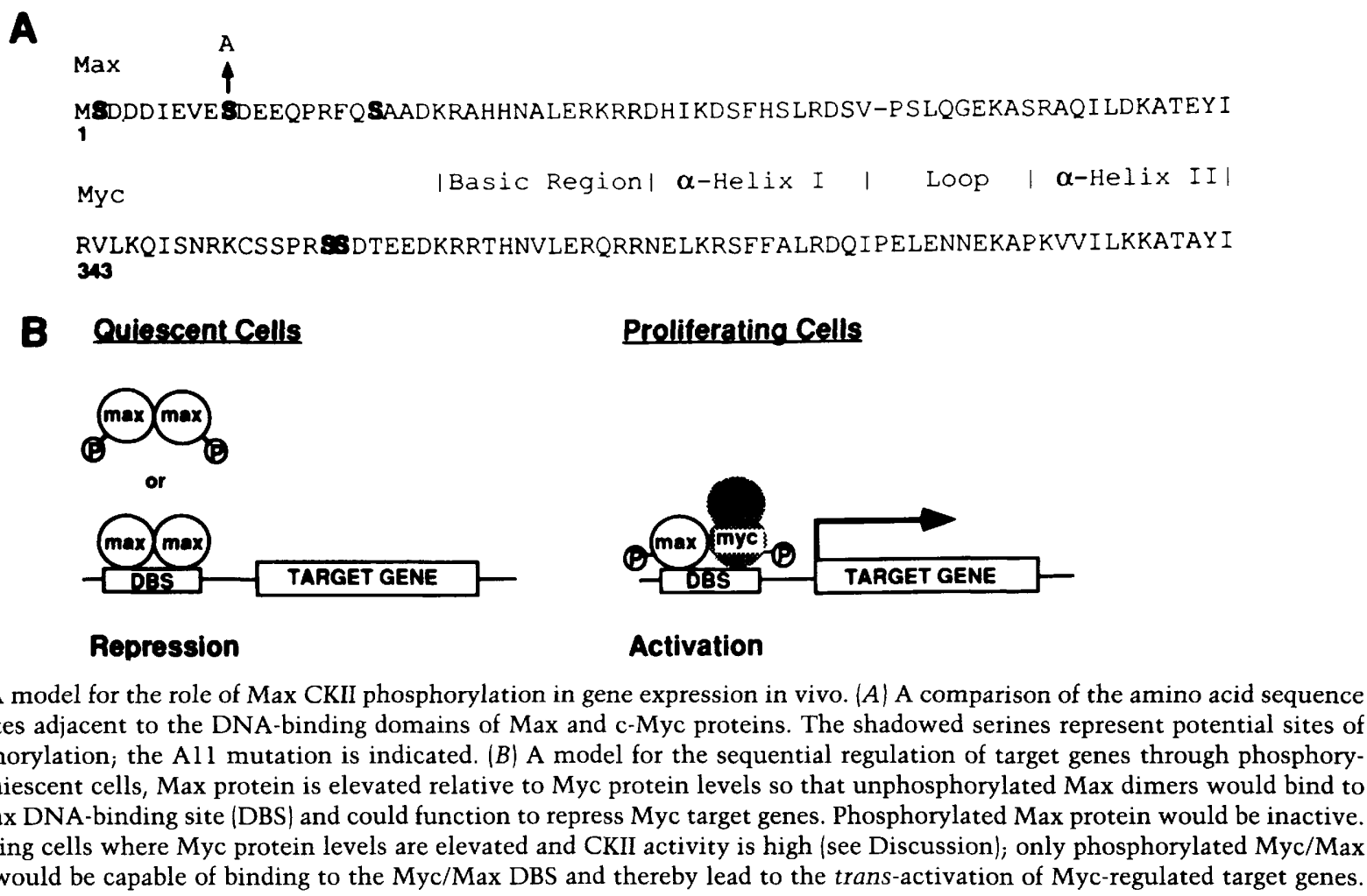

Figure 8. A model for the role of Max CKII phosphorylation in gene expression in vivo. (A) A comparison of the amino acid sequence and CKII sites adjacent to the DNA-binding domains of Max and c-Myc proteins. The shadowed serines represent potential sites of CKII phosphorylation; the All mutation is indicated. (B) A model for the sequential regulation of target genes through phosphorylation. In quiescent cells, Max protein is elevated relative to Myc protein levels so that unphosphorylated Max dimers would bind to the Myc/Max DNA-binding site (DBS) and could function to repress Myc target genes. Phosphorylated Max protein would be inactive. In proliferating cells where Myc protein levels are elevated and CKII activity is high (see Discussion); only phosphorylated Myc/Max complexes would be capable of binding to the Myc/Max DBS and thereby lead to the trans-activation of Myc-regulated target genes. 
we conclude that the carboxy-terminal CKII sites do not function to inhibit DNA-binding activity of Max homodimers. Using site-directed mutagenesis, we demonstrated that the phosphorylation of serine 11 likely inhibits DNA binding of Max homodimers (Fig. 5). However, we cannot exclude the possibility that multiple sites of phosphorylation are necessary to inhibit DNA binding, and elimination of only one of these blocks the effect. Inhibition by the phosphate group might occur by charge repulsion of the DNA molecule, by the phosphate folding in such a way that it neutralizes one of the essential basic residues, or by inducing a change in protein configuration that prevents DNA binding. It is interesting that two alternate forms of Max have been found that differ in precisely the domain phosphorylated by CKII (Blackwood and Eisenman 1991). It will be important to test whether both forms of Max are subject to inhibition by CKII but retain DNA binding when dimerized with Myc. It is intriguing to note a parallel between the inhibitory CKII sites in Max and a protein domain of the E12 form of the E2A gene that inhibits the DNA-binding activity of E12 homodimers, but not heterodimers with MyoD (Sun and Baltimore 1991). Domains such as these may be a general feature of transcription factors that can dimerize with different partners.

Why is the Myc/Max heterodimer not affected by phosphorylation, especially because Myc contains a CKII site immediately upstream of the basic amino acid region at nearly the same location as the middle CKII site of Max (Figs 1A and 8A)? This CKII site proximal to the basic region in $\mathrm{Myc}$ is efficiently phosphorylated in vitro and modified in $\sim 50 \%$ of the Myc protein isolated from cells (Lüscher et al. 1989). Most of the studies described here were performed with a fragment of Myc protein [Myc(c249)] that has an additional cluster of CKII sites (amino acids 245-260), but a truncated protein [Myc(c118)], which retains only the basic region CKII site, still binds DNA when dimerized with phosphorylated Max (Fig. 7 and data not shown) and can be phosphorylated to the same specific activity as the truncated Max protein in vitro (data not shown). Although phosphorylation of Myc does not apparently affect DNAbinding activity in the assays described here, this site is likely to serve an important function as it is conserved in all Myc family genes throughout evolution, including $\mathrm{N}-m y c, \mathrm{~L}-\mathrm{myc}$, and sea urchin myc genes (P. Espenshade and M.D. Cole, in prep.). Furthermore, the avian retroviruses $\mathrm{MC} 29$ and $\mathrm{MH} 2$ have mutations within or near this site that might decrease recognition by CKII /Kan et al. 1983, Watson et al. 1983), and phosphopeptide mapping of mutant MC29 viruses that displayed an altered transformation phenotype all contained deletions of this major phosphorylation site (Bister et al. 1987). Thus, the presence of a phosphate group adjacent to the basic region of both Myc and Max may function to alter the activity of the complex in vivo, perhaps by recognizing slightly different DNA sequences or having an altered affinity that is not distinguished by our in vitro assays.

We believe that Max phosphorylation may function to regulate the in vivo DNA-binding activity of Max ho- modimers in a manner similar to Myb and serum response factor (SRF), two transcription factors in which CKII phosphorylation in vivo modulates DNA-binding capacity (Lüscher et al. 1989; Manak et al. 1990). The modulation in DNA-binding activity afforded by the phosphorylation of Max appears to be even greater $>>40$ fold) than for these other factors. A detailed analysis of the biological activity of mutant Max and Myc proteins that lack CKII sites adjacent to their DNA-binding domains should help to resolve the function of these sites and provide some insight into the general role of transcription factor phosphorylation.

\section{Materials and methods}

Bacterial expression of Max and Myc proteins

Max protein was produced in Escherichia coli by cloning the entire open reading frame from the max cDNA into a BamHI (blunted)-HindIII pDS56(6xHis) vector. The resulting max clone (His-Max) was sequenced to confirm the proper reading frame. Recombinant Max protein was produced using a nickelchelate affinity column as described (Abate et al. 1990). $\operatorname{Max}(\mathrm{n} 110)$ was constructed by a PstI digestion of the His-Max clone, deleting the carboxy-terminal 50 amino acids. Max(Al1) was created using the Kunkel method of site-directed mutagenesis (Sambrook et al. 1989) of pKSMax, converting serine 11 (AGC) to an alanine (GCC). Max(A11) was constructed by polymerase chain reaction (PCR) amplification of the DNA fragment encoding the amino-teriminal 136 amino acids, followed by ligation of the fragment into a HindIII-blunted pDS56 $6 \times$ His $\mid$ vector. $\mathrm{Myc}(\mathrm{cl} 18)$ and $\mathrm{Myc}(\mathrm{c} 249)$ were produced using the pDS56(6xHis) vector and by introducing a BamHI linker into the Pvull site at amino acid 323 of a murine c-myc cDNA [Myc(c118)] or PstI site at amino acid 182 [Myc(c249)] and cloning into pDS56 $(6 \mathrm{xHis})$. The resulting proteins contain 118 and 249 carboxy-terminal amino acids of c-Myc, respectively, and were expressed and purified using nickel-chelate affinity columns. Max and Myc polyclonal anitbodies were prepared from rabbits injected with either purified His-Max or the 392 carboxy-terminal amino acids of murine c-Myc proteins. Preimmune serum was derived from the rabbit used for Max antibody production. The Max antiserum has the following specificity: It will precipitate Max, but not Myc, from in vitro translations and cell lysates; it disrupts EMSA assays with bacterial Max protein, and with cellular Max protein, as shown in the present study; and it does not disrupt other DNA-protein complexes such as USF, as shown by the lack of any change in the EMSA pattern with nuclear extracts (Fig. 6). The Myc antiserum has analogous specificity, and it disrupts the complex between bacterial Myc and Max (not shown).

\section{Electrophoretic band shifts}

Between 35 and $600 \mathrm{ng}$ of bacterially expressed proteins (preincubated for $10 \mathrm{~min}$ at $37^{\circ} \mathrm{C}$ to promote the exchange of dimer subunits/ was incubated for $15 \mathrm{~min}$ at room temperature in a $20-\mu$ l binding buffer $(10 \mathrm{~mm}$ Tris- $\mathrm{Cl}$, at $\mathrm{pH} 7.5,50 \mathrm{~mm} \mathrm{NaCl}, 5$ $\mathrm{mM} \mathrm{MgCl}_{2}, 1 \mathrm{~mm}$ EDTA, $1 \mathrm{~mm}$ DTT) containing $1 \mu \mathrm{g}$ of poly $[\mathrm{d}(\mathrm{I}-\mathrm{C})]$ and $0.2-0.5 \mathrm{ng}$ of ${ }^{32} \mathrm{P}$-labeled MMC probe. The sequence of this probe was GATCCTGACCACGTGGTCTTACGGATC, which has been shown to be an optimal binding site for Myc homodimers (Halazonetis and Kandil 1991), Max homodimers, and Myc/Max heterodimers (Berberich et al. 1992). After incubation, the mixture was loaded onto a $4 \%$ polyacrylamide gel 
and run at room temperature in $0.25 \times \mathrm{TBE}(1 \times \mathrm{TBE}=90 \mathrm{mM}$ Tris-borate, $2 \mathrm{~mm}$ EDTAal $\mathrm{pH} 8.0$ ) until the free DNA had reached the bottom of the gel.

\section{CKII reactions}

Bacterially expressed proteins were incubated with CKII in a $30-\mu$ l reaction $150 \mathrm{~mm}$ Tris- $\mathrm{Cl}$ at $\mathrm{pH} 8.5,100 \mathrm{~mm} \mathrm{NaCl}, 10 \mathrm{~mm}$ $\mathrm{MgCl}_{2}$ ) with $15 \mu \mathrm{Ci}$ of $\left[\gamma^{-32} \mathrm{P} \mid \mathrm{ATP}, 100 \mathrm{mM} \mathrm{ATP}\right.$, for $30 \mathrm{~min}$ at $30^{\circ} \mathrm{C}$. The reactions were terminated by adding SDS-sample buffer. Phosphorylated proteins that had incorporated ATP label were resolved on a $12.5 \%$ SDS-polyacrylamide gel and autoradiographed. EMSAs were performed using bacterially expressed proteins that were incubated with bovine CKII in the presence of ATP or AMP-PNP (except that $\left[\gamma^{-32}\right.$ P]ATP was omitted and reactions were terminated by the addition of AMP-PNP). The proteins were assayed in band-shift reactions that included 5 mM AMP-PNP. CKII enzyme was purified from bovine liver as described previously (Yu et al. 1991).

\section{Glutaraldehyde cross-linking reactions}

Bacterially expressed Max proteins were incubated with CKII in the presence of $3 \mathrm{~mm}$ ATP (MaxP) or $3 \mathrm{~mm}$ AMP-PNP as described above. Approximately $200 \mathrm{ng}$ of Max or MaxP was incubated with increasing concentrations of glutaraldehyde $10 \%$, $0.001 \%, 0.005 \%, 0.025 \%$ ) in a $25-\mu \mathrm{l}$ reaction containing $25 \mathrm{~mm}$ HEPES (pH 7.5), $50 \mathrm{mM} \mathrm{KCl}, 1 \mathrm{mM}$ EDTA, and $8 \%$ glycerol for $30 \mathrm{~min}$ at $30^{\circ} \mathrm{C}$. Reactions were terminated by adding SDSsample buffer, and boiling for $5 \mathrm{~min}$, and proteins were resolved on a $12.5 \%$ SDS-polyacrylamide gel. Max protein was visualized by Western transfer and subsequent probing with streptavidin-conjugated Max polyclonal antibody.

\section{Overexpression of Max in NIH-3T3 cells}

NIH-3T3 cells were transfected with a Max cDNA expression vector (CMV-max; full-length murine max cDNA linked to the CMV promoter) or cotransfected with Max and Myc expression vectors (CMV-max and CMV-myc, full-length cDNA murine c-myc gene). MaxD and MMB represent two stable transfected cell lines that overexpress Max 5- to 10-fold, based on RNA and protein levels. MMB also overexpresses Myc RNA approximately fourfold.

\section{EMSA with nuclear extracts}

Nuclear extracts were prepared using the standard Dignam method (Dignam et al. 1983). Up to $2 \mu l$ of extract was used in a 20- $\mu$ l binding reaction. Extracts were phosphatased by the addition of $1.5 \mu \mathrm{g}$ of PAP per reaction (Boehringer Mannheim) and incubated at $37^{\circ} \mathrm{C}$ before the addition of probe and antibody. EMSA reactions that included $\mathrm{Myc}(\mathrm{c} 249)$ were preincubated for an additional $10 \mathrm{~min}\left(37^{\circ} \mathrm{C}\right)$ following phosphatase treatment before the addition of probe.

\section{Immunopreciptation of Max from NIH-3T3 cells}

Approximately $10^{8} \mathrm{NIH}-3 \mathrm{~T} 3$ cells were washed in PBS and lysed in $1 \mathrm{ml}$ of $50 \mathrm{~mm}$ Tris- $\mathrm{Cl}(\mathrm{pH} 7.5), 150 \mathrm{~mm} \mathrm{NaCl}, 1 \mu \mathrm{g} / \mathrm{ml}$ of aprotinin, $100 \mu \mathrm{g} / \mathrm{ml}$ of PMSF, and $1 \% \mathrm{NP}-40$ for $30 \mathrm{~min}$ at $4^{\circ} \mathrm{C}$. The resulting supernatant was immunoprecipitated with 1.25 $\mu g$ of IgG-purified Max polyclonal antibody. The antibody was recovered using protein A-Sepharose, washed three times with $\mathrm{PBS}$, and denatured from the recovered Max protein by resuspending the beads in $300 \mu \mathrm{l}$ of $6 \mathrm{M}$ guanidine- $\mathrm{HCl}, 20 \mathrm{mM}$ Tris-
$\mathrm{Cl}$ (pH 7.9), $100 \mathrm{~mm} \mathrm{KCl}, 0.2 \mathrm{~mm}$ EDTA, 0.05\% NP-40, $0.5 \mathrm{~mm}$ DTT, $0.5 \mathrm{mM}$ PMSF, and $20 \%$ glycerol. The protein was renatured by dialysis in $25 \mathrm{~mm} \mathrm{NaHPO}, 2.5 \mathrm{~mm}$ DTT, and $5 \%$ glycerol. Up to $10 \mu$ l of renatured protein was used in an EMSA assay.

\section{Acknowledgments}

We thank Dan Marshak for providing CKII, and N. HydeDeRuyscher and Peter Espenshade for their excellent technical assistance. This work was funded by grants from the National Institutes of Health $(\mathrm{NIH})$ and the Pew Memorial Trust to M.D.C. S.J.B. is a recipient of a NIH postdoctoral fellowship.

The publication costs of this article were defrayed in part by payment of page charges. This article must therefore be hereby marked "advertisement" in accordance with 18 USC section 1734 solely to indicate this fact.

\section{References}

Abate, C., D. Luk, R. Gentz, F.J. Rauscher, and T. Curran. 1990. Expression and purification of the leucine zipper and DNAbinding domains of Fos and Jun: Both Fos and Jun contact DNA directly. Proc. Natl. Acad. Sci. 87: 1032-1036.

Ackerman, P. and N. Osheroff. 1989. Regulation of casein kinase II activity by epidermal growth factor in human A-431 carcinoma cells. I. Biol. Chem. 264: 11958-11965.

Beckmann, H., L.-K. Su, and T. Kadesch. 1990. TFE-3: A helixloop-helix protein that activates transcription through the immunoglobulin enhancer $\mu \mathrm{E} 3$ motif. Genes \& Dev. 4: 167179.

Berberich, S.J., N. Hyde-DeRuyscher, P. Espenshade, and M.D. Cole. 1992. Max encodes a sequence-specific DNA binding protein and is not regulated by serum growth factors. Oncogene (in press).

Bister, K, C. Trachmann, H.W. Jansen, B. Schroeer, and T. Patchinsky. 1987. Structure of mutant and wild-type MC29 $\mathrm{v}$-myc alleles and biochemical properties of their protein products. Oncogene 1: 97-109.

Blackwood, E. M. and R.N. Eisenman. 1991. Max: A helix-loophelix zipper protein that forms a sequence specific DNAbinding complex with Myc. Science 251: 1211-1217.

Boulton T.G., S.H. Nye, D.J. Robbins, N.Y. Ip, E. Radziejewsha, S.D. Morgenbesser, R.A. DePinho, N. Panayotatoss, M.H. Cobb, and G.D. Yancopoulos. 1991. ERKs: A family of protein-serine/threonine kinases that are activated and tyrosine phosphorylated in response to insulin and NGF. Cell 65: 663-675.

Boyle W.J., T. Smeal, L.H.K. Defize, P. Angel, J.R. Woodgett, M. Karin, and T. Hunter. 1991. Activation of protein kinase C decreases phosphorylation of c-Jun at sites that negatively regulate its DNA binding activity. Cell 64: 573-584.

Carroll, D. and D.R. Marshak. 1989. Serum-stimulated cell growth causes oscillations in casein kinase II activity. I. Biol. Chem. 264: 7345-7348.

Cohen, P. 1988. The structure and regulation of protein phosphatases. Annu. Rev. Biochem. 58: 453-508.

Cole, M.D. 1986. The myc oncogene: Its role in transformation and differentiation. Annu. Rev. Genet. 20: 361-384.

Dignam, J.D., R.M. Lebovitz, and R.G. Roeder. 1983. Accurate transcription initiation by RNA polymerase II in a soluble extract from isolated mammalian nuclei. Nucleic Acids Res. 11: 1475-1489.

Edelman A.M., D.K. Blumenthal, and E.G. Krebs. 1987. Protein serine/threonine kinases. Annu. Rev. Biochem. 56: 567-613. 
Firzlaff, J.M., D.A. Galloway, R. Eisenman, and B. Lüscher. 1989. The E7 protein of human papillomavirus type 16 is phosphorylated by casein kinase II. New Biol. 1: 44-53.

Freytag, S., C. Dang, and W. Lee. 1990. Definition of the activities and properties of c-Myc required to inhibit cell difierentiation. Cell Growth Differ. 1: 339-343.

Gauthier-Rouviere, C., M. Basset, J.-M., Blanchard, J.-C. Cavadore, A. Fernandez, and N.J.C. Lamb. 1991. Casein kinase II induces c-fos expression via the serum response element pathway and $\mathrm{p} 67^{\mathrm{SRF}}$ phosphorylation in living fibroblasts. EMBO I. 10: 2921-2930.

Gregor, P.D., M. Sawadogo, and R.G. Roeder. 1990. The adenovirus major late transcription factor USF is a member of the helix-loop-helix group of regulatory proteins and binds to DNA as a dimer. Genes \& Dev. 4: 1730-1740.

Halazonetis, T. and A.N. Kandil. 1991. Determination of the c-MYC DNA-binding site. Proc. Natl. Acad. Sci. 88: 61626166.

Hann, S.R. and R.N. Eisenman. 1984. Proteins encoded by the human c-myc oncogene: Differential expression in neoplastic cells. Mol. Cell. Biol. 4: 2486-2497.

Hathaway, G.M. and J.A. Traugh. 1979. Cyclic nucleotide-independent protein kinases from rabbit reticulocytes: Purification of casein kinases. J. Biol. Chem. 254: 762-768.

Hu, Y.-F., B. Lüscher, A. Adman, N. Mermond, and R. Tijan. 1990. Transcription factor AP-4 contains multiple dimerization domains that regulate dimer specificity. Genes \& Dev. 4: 1741-1752.

Kan, N.C., C.S. Flordellis, C.F. Garon, P.H. Duesberg, and T.S. Papas. 1983. Avian carcinoma virus $\mathrm{MH}-2$ contains a transformation specific sequence mht and shares the myc sequence with MC-29, CM-II, and OK-10 viruses. Proc. Natl. Acad. Sci. 80: 6566-6570.

Kapiloff, M.S., Y. Farkash, M. Wegner, and M.G. Rosenfeld. 1991. Variable effects of phosphorylation of Pit-1 dictated by the DNA response elements. Science 245: 786-789.

Karlund, J.K. and M.P. Czech. 1988. Insulin-like growth factor I and insulin rapidly increase casein kinase II activity in BALB/c 3T3 fibroblasts. /. Biol. Chem. 263: 15783-15875.

Kato, G.J., J. Barrett, M. Villa-Garcia, and C.V. Dang. 1990. An amino-terminal c-Myc domain required for neoplastic transformation activates transcription. Mol. Cell. Biol. 10: 5914 5920.

Landschulz, W.H., P.F. Johnson, and S.L. Mcknight. 1988. The leucine zipper a hypothetical structure common to a new class of DNA-binding proteins. Science 240: 1759-1764.

Lüscher, B. and R.N. Eisenman. 1990. New light on Myc and Myb. Part 1. Myc. Genes \& Dev. 4: 2025-2035.

Lüscher, B., E.A. Kuenzel, E.G. Kriebs, and R.N. Eisenman. 1989. Myc oncoproteins are phosphorylated by casein kinase II. $E M B O$ I. 8: 1111-1119.

Lüscher, B., E. Christenson, D.W. Litchfield, E.G. Krebs, and R.N. Eisenman. 1990. Myb DNA binding inhibited by phosphorylation at a site deleted during oncogenic activation. Nature 344: 517-521.

Manak, J.R., N. de Bisschop, R.M. Kris, and R. Prywes. 1990. Casein kinase II enhances the DNA binding activity of serum response factor. Genes \& Dev. 4: 955-967.

Murre, C., P.S. McCaw, and D. Baltimore. 1989. A new DNA binding and dimerization motif in immunoglobulin enhancer binding, daughterless, $\mathrm{myoD}$, and myc proteins. Cell 56: $777-784$.

Prendergast, G.C., D. Lawe, and E.B. Ziff 1991. Association of Myn, the murine homolog of Max, with c-Myc stimulates methylation-sensitive DNA binding and ras cotransformation. Cell 65: 395-407.
Sambrook, J., E.F. Fritsch, and T. Maniatis. 1989. Molecular cloning: A laboratory manual, 2nd ed. Cold Spring Harbor Laboratory Press, Cold Spring Harbor, New York.

Smith, M.J., P.C. Charron-Prochownik, and E.V. Prochownik. 1990. The leucine zipper of c-Myc is required for full inhibition of erythroleukemia differentiation. Mol. Cell. Biol. 10: $5333-5339$.

Sommercorn, J., J.A. Mulligan, F.J. Lozeman, and E.G. Krebs. 1987. Activation of casein kinase II in reponse to insulin and to epidermal growth factor. Proc. Natl. Acad. Sci. 84: 8834 8838.

Sorger, P.K. and J.R.B. Pelham. 1988. Yeast heat shock factor is an essential DNA-binding protein that exhibits temperature-dependent phosphorylation. Cell 54: 855-864.

Stone, J., T. De Lange, G. Ramsay, E. Jakobovits, J.M. Bishop, H. Varmus, and W. Lee. 1987. Definition of regions in human c-myc that are involved in transformation and nuclear localization. Mol. Cell. Biol. 7: 1697-1709.

Sun, X.-H., and D. Baltimore. 1991. An inhibitory domain of E12 transcription factor prevents DNA binding in E12 homodimers but not in E12 heterodimers. Cell 64: 459-470.

Watson, D.K., E.P. Reddy, P.H. Duesberg, and T.S. Papas. 1983. Nucleotide sequence analysis of the chicken c-myc gene reveals homologous and unique coding regions by comparison with the transforming gene of avian myelocytomatosis virus MC-29 delta-gag-myc. Proc. Natl. Acad. Sci. 80: 2146-2150.

Yamamoto, K.K., W.H. Gonzalez, W.H. Biggs III, and M.R. Montiminy. 1988. Phosphorylation-induced binding and transcriptional efficacy of nuclear factor CREB. Nature 334: 494-498.

Yu, I.J., D.I. Spector, Y.S. Bae, and D.R. Marshak. 1991. Immunochemical localization of casein kinase II during interphase and mitosis. I. Cell Biol. 114: 1217-1232. 


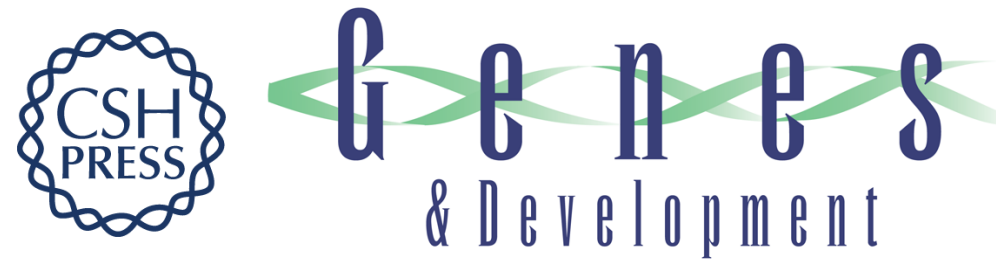

\section{Casein kinase II inhibits the DNA-binding activity of Max homodimers but not Myc/Max heterodimers.}

S J Berberich and M D Cole

Genes Dev. 1992, 6:

Access the most recent version at doi:10.1101/gad.6.2.166

References This article cites 39 articles, 21 of which can be accessed free at:

http://genesdev.cshlp.org/content/6/2/166.full.html\#ref-list-1

License

Email Alerting

Service

Receive free email alerts when new articles cite this article - sign up in the box at the top right corner of the article or click here.

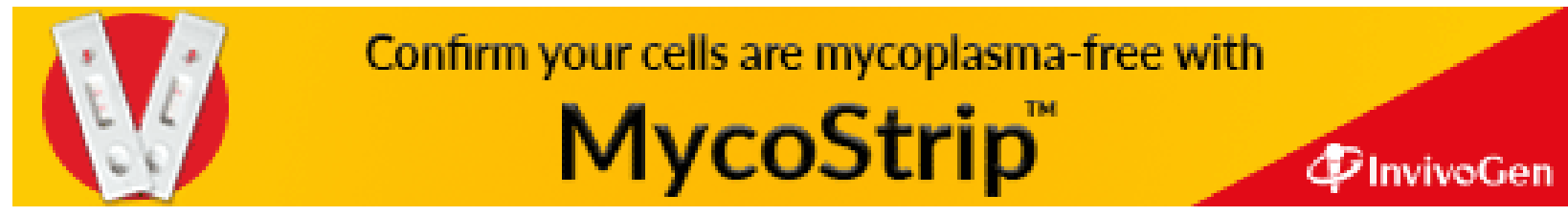

